\title{
In the Pursuit of Sustainability: Lessons from the Coffee Sector
}

\section{Robert Armstrong Rice}

Migratory Bird Center, Smithsonian Biological Conservation Institute, National Zoological Park, Washington, USA

\author{
Email address: \\ ricer@si.edu
}

\section{To cite this article:}

Robert Armstrong Rice. In the Pursuit of Sustainability: Lessons from the Coffee Sector. International Journal of Environmental Protection and Policy. Vol. 3, No. 1, 2015, pp. 14-19. doi: 10.11648/j.ijepp.20150301.12

\begin{abstract}
Recent years have shown an impressive and growing concern about sustainable production of food, fiber and oil crops. As more crops become incorporated into the sustainability realm, which often involves a certification of prescribed production methods/conditions, lessons can be learned from sectors with extant sustainability initiatives. For biofuels, a sector with rapidly expanding areas devoted to cropland worldwide and some debated benefits in both social and environmental issues, lessons from the sustainable coffee sector's history and development can provide insights about possible paths toward sustainability. This paper presents some of the history and development of the sustainable coffee sector, emphasizing the role of science and inter-institutional relations in the emergence of several initiatives. A number of key issues and themes to consider are explored, hopefully providing some direction to those in the biofuels sector with an interest in sustainability.
\end{abstract}

Keywords: Sustainability, Coffee, Biofuels, Certification, Eco-Labels

\section{Introduction}

Integrating agricultural markets of countries where there is potential for providing feedstock at low cost [i.e., the Global South] with fuel demands of the high-consuming countries [mostly the Global North] will speed the deployment of biofuel technology. Rapid deployment will present environmental and social sustainability challenges. Creating and implementing a certification system based on sustainability criteria could play an important role in addressing these challenges and ensuring that biofuels are produced in a responsible manner.

--World Business Council for Sustainable Development

(emphases added)

...society also cannot accept the undesirable impacts of biofuels done wrong.

--Tilman et al, 2009

The quotes above acknowledge the obvious challenge in addressing the sustainability of the fast-growing biofuels sector. Environmental and socioeconomic sustainability issues rank as important concerns in any sector, particularly one where foodstuffs and habitats receive frequent mention as suffering at the expense of its unchecked growth ([1]; [2]; [3]; [4]). As the biofuel industry searches for ways to meld production and sustainability, it is instructive to borrow from the sustainable coffee movement's history so as to understand how criteria related to sustainability emerged, evolved and, ultimately, have been applied. While coffee and biofuels hardly compare in terms their respective importance for our sustainable future, the process, interactions and current status of the sustainable coffee movement can prove instructive for an expanding industry that is poised to expand even more as much as biofuels.

Both coffee and many biofuels (sugarcane, oil palm, maize, jatropha) are grown in the tropics. Few tropical products involve the number of landowners, workers, processors, and traders as our morning cup of coffee. Some 125 million people's livelihoods depend upon its journey from tree to cup, facilitating an annual consumption of more than 600 billion cups [5]. And specialty coffee in particular has seen tremendous growth over the past three decades. Coffee's importance globally and locally is difficult to overstate, especially to those 60 countries involved in providing it to the world. But with future energy demands, biofuels' reach will likely grow to penetrate more deeply and pervasively into our daily lives in ways coffee never could. But unlike coffee, a product managed by large and small landowners alike, the current trend of expanding areas for tropical 
biofuels features large industrial operations with debatable socioeconomic benefits for local communities [6].

Contrasting to coffee's global consumption and growing popularity worldwide is a scant understanding by consumers of the varied management practices involved in its production. Compared to basic grains like corn, rice and wheat, the Green Revolution trappings of high-yielding varieties, machinery in the fields, and the use of petroleumderived inputs like herbicides, insecticides, fungicides and fertilizers came late - if at all — to coffee famers. For many growers these technologies changed the cultural practices in dramatic ways over the past several decades. This "modernization" of production usually included a loss of coffee's traditional shade canopy, a management practice that mimics coffee's evolutionary setting as an understory shrub in the forests of east Africa's highlands [7].

This dichotomy of modern -- or "technified" -- coffee and traditional shade-grown coffee led to the development of a number of initiatives in the 1990s that involved the verification or inspection/certification of what has evolved into "sustainable" coffee. Prior to this, however, organic and fair trade certifications accompanied coffee trading as early as the 1960s [8]. The notion of "sustainable coffee" came later, impulsed by a combination of scientific evidence about the role shade coffee can play ecologically, expanding markets and general consumer interest in both fair trade and organic certified products, and a number of initiatives from a range of organizations. The roots of the initial programs grew out of ornithological fieldwork in coffee areas of Mexico and Guatemala [9], [10, 11, 12]. The emergence and spread of both fair trade and organic coffee's popularity, as well as a growing interest in sustainability in general, certainly figure as factors in the growth of sustainable coffee.

This paper focuses on the emergence, development and current status of sustainable coffee, with an emphasis on the environmental aspects of sustainability. Its history is linked to the specialty coffee sector, a sub-set of the larger commodityfocused coffee industry. With beginnings that involved nongovernmental organizations (NGOs), a handful of forwardlooking private concerns, and some state and quasi-state agencies in both producing and consuming countries, sustainable coffee can claim pioneer status as being the product that brought environmental, social and economic awareness about its production and trade to end consumers. The terms "sustainable" and "sustainability" in reference to coffee make it one of the first commodities to have criteria developed that focus on its environmental, social and economic characteristics. A number of initiatives that began in the 1990s and beyond are currently in place and being used to define coffee sustainability at the level of production and trade.

\section{History of Sustainable Coffee's Beginnings and Development}

Surveys of birds in western Guatemala in the late 1980s and into the 1990s by Vannini [9] revealed that migratory birds make use of coffee farms. In 1994, after nearly four years of researching bird communities in southern Mexico, Dr. Russell Greenberg, a Smithsonian Institution ornithologist, knew that coffee farms managed in particular ways-especially those of small peasant growers who managed a diverse shade canopy and could not afford chemical inputs - served as quality habitat for migratory and resident birds $[10,11]$. Together with the Seattle Aububon Society, the Woodland Park Zoo and a local environmental NGO, Greenberg invited two Seattle-based roastersStarbucks Coffee and Seattle's Best Coffee-to a seminar and discussion that featured a presentation based on his findings in Mexico: "The Coffee Connection, Politics, Biodiversity and Sustainable Agriculture: A Case history from Chiapas, Mexico". The event aimed to describe the benefits that migratory birds derive from coffee cultivation in the tropics.

In mid-1994, the Specialty Coffee Association of America (SCAA) created the Environmental Policy Task Force, a subgroup to its Technical Advisory Committee. The task force's charge was to look into the environmental impact of the worldwide coffee industry, according to its director, a roaster who later joined in the discussions to form the Coalition for Sustainable Coffee.

A number of people from organizations representing NGOs and the private sector began meeting in early 1995 in the hopes for forming what they called the Coalition for Sustainable Coffee. This group included fair trade, environmental, policy, research and business interests, and all involved were seeking ways to combine the efforts and ultimate certification of organic coffee, fair trade coffee and a new concept of biodiversity-focused coffee under one "sustainable coffee" initiative. The notion was one of creating a set of criteria with a recognizable seal that would be part of a larger campaign aimed at both environmental and social reform of the US coffee industry. The three-fold goal was to slow the destruction of tropical deforestation and protect biodiversity, improve the incomes and lives of peasant coffee farmers, and teach consumers about sustainability through coffee. In order to accomplish these aims, this small group sought funding for a 100-day strategic planning process, the results of which would be 1) social and environmental criteria for sustainable coffee production, 2) a white paper on sustainable coffee, 3) a 3-year strategic work plan, 4) agreements on the certification program and conceptual artwork for the seal, and 5) bylaws, structure, incorporation papers, a name, and funding proposals for new organization [13]. In fact, one of Equal Exchange's (a roasting company dedicated to fair trade coffee) founding members urged these early participants who were rolling out some of the best thinking on sustainability and coffee to merge efforts into a harmonized initiative and seal. These well-intentioned efforts were never funded, and the urge to merge was never acted upon. But the seeds for sustainable coffee were sown, and a white paper on sustainable coffee did emerge [14].

The landmark event that many in the coffee industry point 
to as a catalyst to the sustainable coffee movement occurred in 1996 in Washington, DC. Scientists at the Smithsonian Institution organized a three-day conference called "The First Sustainable Coffee Congress (FSCC)", in which nearly 300 attendees from 19 countries came together to discuss sustainability within the coffee sector [15]. From the presentations, panel discussions and working groups that formed the formal activities of the conference, fifty-eight people representing all segments of the coffee commodity chain signed the "Resolution of the First Sustainable Coffee Congress", which stated:

$\mathrm{Be}$ it resolved that we, the undersigned participants of the first sustainable Coffee Congress, are committed to the advancement of sustainable coffee in the marketplace. Sustainable coffee is grown in a high-diversity, low-input system and is produced in a way that conserves resources, protects the environment, produces efficiently, competes commercially and enhances the quality of life for farmers, farm communities, brokers, roaster, vendors, consumers and people in both producing and consuming nations as a whole.

The congress organizers followed up by trying to form a coalition centered around the concept of sustainable coffee. By this time, however, the various missions of various NGOs and the market interests of different groups and private concerns had developed to the point that most parties wanted to go their own way. Others, like a Ford Foundation grant manager already involved with fair trade coffee, thought the idea "a great shame", explaining that a single industrysanctioned coalition would confuse consumers [13]. A concerted effort never materialized.

What did materialize, however, was a flurry of efforts on the part of roasters to take "shade-grown" coffee to the market. While the FSCC had focused on various aspects of sustainability, the ornithological data that linked diversely shaded coffee systems with a forest-like canopy to bird diversity caught the attention of many. A post-congress meeting, in which some of the scientists tried to enlist roasters in an effort to develop criteria and a label for shade-grown coffee, yielded few results. But the information and discussions did induce several attending roasters to take the coffee-as-habitat message to consumers on their own. At this point, the concept of shade coffee became a surrogate for sustainable coffee. The explosion of marketing efforts and strategies that began using the term "shade" and bird images on coffee packaging was truly impressive. The development of criteria for sustainable coffee was left to the NGOs and others.

\section{Early Initiatives with Criteria}

By the mid-1990s, some coffee companies, research groups and NGOs foresaw the sustainable coffee concept as an avenue to funding, environmental protection and/or potential revenue. Fair trade (FT) certification, which had existed for years in Europe and more recently with roasters like Equal Exchange in Massachusetts, focused on social and economic issues for small producers who were organized in democratically run organizations. But FT had few if any specific environmental criteria at the time. But prior to the 1996 conference in Washington, DC, the international environmental group Rainforest Alliance (RA) had created some criteria and launched a coffee certification program that followed its success with having certified bananas as "EcoOK". The Eco-OK criteria included social, economic and environmental metrics, creating a seal more in line with the holistic notion of sustainability. Because of European Union regulations that saw "eco" as a designation for "certified organic" -which the bananas were not necessarily-RA soon dropped the term and changed its labeling to "Rainforest Alliance Certified" to allow product entry into European Union markets. RA went on to become the most recognizable of several "sustainable coffee" seals.

Other organizations were developing criteria, alliances and certification programs geared toward the idea of sustainable coffee. Ecologists and ornithologists at the Smithsonian Institution (SI) who had been pushing for some years to create shade standards, introduced criteria to accompany certified organic coffee and established the "Bird Friendly" certification - a shade certification focused on the habitat capability of diverse shade coffee systems. The SCAA's task force (see above) became a bona fide stand-alone Environment Committee in the late 1990's, and took on the challenge of developing shade criteria for its parent organization. The SCAA Board of Directors never acted upon the committee's recommendation to define shade coffee. The Washington, DC-based environmental organization, Conservation International (CI), developed a program that defined "Conservation Coffee", sourced from the southern Mexico region near the El Triunfo National Park in Chiapas. Not a coffee with a certification per se, the shade coffee was verified as such by CI staff in the field. CI partnered with Starbucks Coffee, which sold the coffee from this program as a shade-grown offering to its customers, and later helped develop Starbucks' C.A.F.E. Practices Program.

\section{Common Work with Consumer's Choice Council and Beyond}

An important actor in the early efforts to coordinate programs and certification standards was the US-based Consumer's Choice Council, headed by Chad Dobson. Noting the growing interest in sustainable coffee, Dobson worked to bring several organizations together to discuss and hammer out basic standards around what a sustainable coffee might be. In 2001, these efforts emerged as the "Conservation Principles for Coffee Production", signed on to and endorsed by 16 organizations involved in coffee production issues [16]. The principles addressed eight distinct categories that included, among others, sustainable livelihoods, ecosystem and wildlife conservation, soil conservation, water protection and conservation, and pest and disease management. The goals of the principles had the following in mind: 
- align coffee production with biodiversity conservation;

- create tools and incentives that promote and reward good stewardship in the coffee industry;

- strengthen collaboration and facilitate local standards development;

- inform planning and monitoring;

- influence public policy and financing.

A number of organizations working to create this set of basic principles soon went their separate ways, concentrating on their respective missions to elaborate more detailed criteria-most of which agree with the basic principles. By the early 2000 's, sustainable coffees were being promotedsome with third party inspection, some without-by Rainforest Alliance (with its own initiative and also one with Nestlé), Conservation International/Starbucks, the Smithsonian Migratory Bird Center, Utz Kapeh (later changed to Utz Good Inside) and the 4C program. All carry some sort of seal to certify or at least verify adherence to some set of standards $[17,18,19,20,21]$. A timeline of these initiatives' appearance is provided in Figure 1. And by the mid-2000s, certified coffees accounted for $30 \%$ of all coffee in the Netherlands and eight percent of the US market [8].

At this time also the Consumer's Choice Council enlisted Robert Goodland of the World Bank to write a background paper, "Ecolabeling: Opportunities for Progress Toward Sustainability", a general assessment of the value of ecolabels on various products and how "greenness" has considerable commercial power [22]. The conclusion was that "ecolabeling works"-both nationally and internationally — and that institutions need to get involved via "green procurement" policies. Two years later, using a value chain approach at the global level, Ponte assessed the sustainable coffee sector in a report funded by the International Institute for Sustainable Development (IISD), making the point (among others) that producers need to be included in discussions and development of sustainability standards for the benefit of overall governance of the global value chain [23].

Org: 1960s

$$
\text { UTZ }
$$

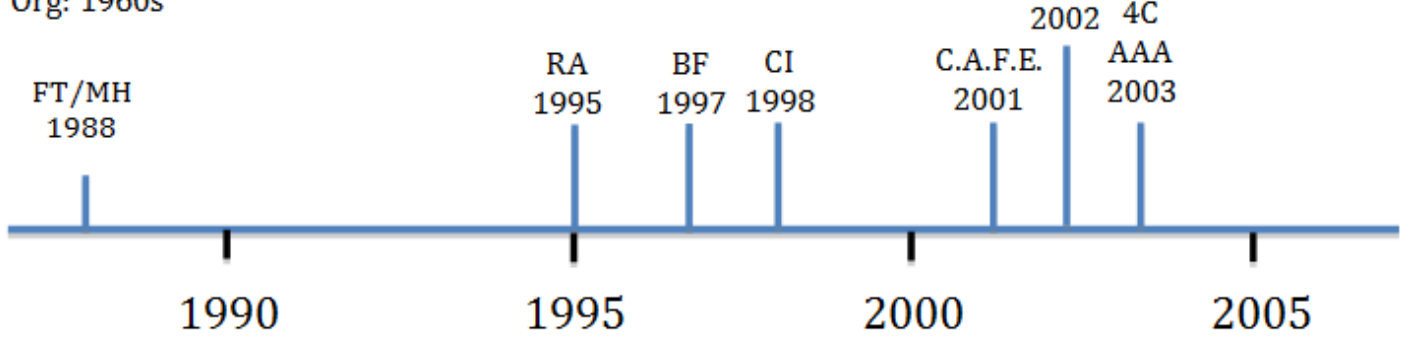

Org: Organic certified coffees; FT/MH: Fair Trade/Max Havelaar; RA: Rainforest Alliance; BF: Smithsonian's Bird Friendly; CI: Conservation International's Conservation Coffee Program with Starbucks; C.A.F.E.: Starbucks' CAFÉ Practices; Utz: Utz Certified Good Inside; 4C: Common Code for Conservation Coffee; AAA: Nespresso AAA Program of Nestlé..

Figure 1. Timeline of Sustainable Coffee Programs

By 2010, the Scientific and Technical Advisory Panel (STAP) of the UN's Environmental Program, produced a document entitled "Environmental Certification and the Global Environment Facility" [24]. While this document's aim was to provide the GEF community with information relevant to its funding of eco-certification projects on an array of products, sustainable coffee's role in generating interest and attention to eco-labeling in general is evidenced by the cover art on the document: roasted coffee beans. Price premiums and access to markets were laid out as crucial elements for any "predefined environmental and social welfare production standards" to work successfully. The key messages brought to light include: threats to eco-certification effectiveness and how to minimize them; a need for rigorous studies that can measure the environmental and socioeconomic impact of certification programs aimed at sustainability; and a plea to finance projects or initiatives that present a design to evaluate the impacts. Moreover, in accordance with discussions that had already occurred in the early stages of the sustainable coffee efforts, the report acknowledged that any program seeking to improve producers' environmental and/or socioeconomic performance must involve a price premium associated with the certified product that is high enough — or access to markets valuable enough-to offset certification costs and attract viable numbers of producers. Such advise is relevant to any effort that attempts to claim sustainable production, biofuels included.

\section{Key Issues Relevant to Sustainable Biofuels' Development and Markets}

Most students and participants of the sustainable coffee movement agree that the term "sustainable" must include the economic, environmental and social landscapes. Many also agree that some sort of inspection and certification, underpinned by transparency, are essential for consumer confidence in any eco-label. While record keeping and paperwork can be time-consuming and tedious, the benefits of traceability can arguably outweigh the costs of oversight, particularly where consumers may question any given aspect of conditions at origin or with trade. For those contemplating an expanding production and market for sustainable biofuels, 
it is worth considering a few issues that have emerged within the sustainable coffee sector.

Aside from the recurrent question as to whether and how best to combine different initiatives into a "super label" that not only covers all aspects of production and trade-e.g., a triple certification that addresses environmental issues like soil/water protection, socioeconomic issues like prices and worker well-being, and habitat/biodiversity issues such as vegetation management-discussions about farm-level versus landscape-level approaches to sustainability have emerged as pertinent and central questions. For sustainability to work in all these areas of concern, the argument for a landscape or watershed approach is quite valid. More discussion among the various actors involved is certainly in order for such scaling up to work successfully, a process recently started by a number of researchers familiar with the sustainable coffee sector [25]. This same publication lays out three important components to any viable certification system seeking to verify sustainably produced products.

Monitoring and assessment of how any sustainable initiative performs are essential for its continued existence. Its positive impact on producers' well-being, as well as that of the environment, is paramount if consumers are expected to support a program for the long term. An evaluation of sustainable coffee programs showed that more attention is needed in this realm [26]. Monitoring also refers to the governance of the program itself, which must have standards strict enough and enforcement robust enough to weed out poorly performing producers [24].

Transparency is essential if widespread acceptance of a sustainable biofuel sector is to succeed. From the initial development of criteria to the production and trade of biofuels, a free and open access to all aspects of the product's life cycle will generate good will with consumers and serve to emphasize the responsible commitment to sustainability on the part of producers and traders.

The role of science in establishing a set of criteria for any standard is critical. For any agricultural system to claim sustainability - especially as it relates to ecological processes, biodiversity protection/maintenance, or other environmental issues such as water quality, soil protection, carbon sequestration, etc. - the criteria involved should be based on science. The environmental claims witnessed within the sustainable coffee sector have varied greatly. The issue of shade coffee providing viable habitat for wildlife, for instance, has a peer-reviewed body of literature to support the criteria developed by groups like Rainforest Alliance and the Smithsonian Institution's Migratory Bird Center. Yet, in efforts to capture market shares, many coffee producers and roasters self-assess the habitat quality of farms that often overstates the sustainable nature of the holdings. Moreover, such self-monitoring introduces the possibility of conflict of interest issues.

A period for public comment on whatever criteria and assessment mechanisms are proposed serves as a tangible way for interested parties to be involved in the process toward an acceptable set of criteria.
Claims of sustainable production are best supported by information from independent third parties. A viable model for the third-party assurance is the organic certification community. Regardless of whether a system qualifies as organic, the inspection and certification involved in determining its sustainable nature can best be assured via independent assessment from a disinterested entity. This helps to eliminate any question of conflict of interest on the part of producers and traders.

Scale is an issue. How best to define sustainable production? Is a farm-level approach sufficient, or should the assessment focus at the landscape or watershed level? For landowners and certification agencies, defining sustainability at the farm level can be preferable. Yet, for the maintenance of biological corridors and connectivity within the landscape matrix, a geographic area larger than a single farm is preferable when considering overall sustainability. With the likelihood that biofuels will be concentrated in specific areas conducive to their production, the landscape mosaic should conserve habitat connectivity - a feature that might better be handled by collective effort on the part of all landowners in a region. And consolidating efforts and acting as a group would also allow for greater leverage in negotiating social and economic returns from providing sustainable biofuels.

Another issue to consider is product purity. That is, at the final consumer end of the product's life cycle-in this case, the biofuel being used for energy production in some wayhow pure is the product in terms of sustainability? Has the sustainably produced and certified biofuel been diluted by mixing with product that does not meet sustainable standards? Certain uses may demand a degree of mixing in order for the biofuel to perform optimally, but as new technologies related to biofuels emerge, the product purity issue may play an important role in consumers' attitudes and actual purchases.

Finally, institutional involvement can and should play a central role in developing a successful sector for sustainable biofuels. Sustainable coffee grew out of non-governmental organizations' initiatives for the main part, and found adoption from a number of private sector interests (e.g., Starbucks, Kraft, Nestlé). But decisions by governments and institutions to include sustainably produced coffee in procurement have lagged by comparison. For the biofuels sector that is experiencing the "rapid deployment" cited at the top of this paper [27], government involvement evident, at least in terms of subsidies and procurement. But for sustainable biofuels to be successful in the marketplace, buyin from institutions and policymakers in terms of support for the scientific underpinnings of the criteria development, as well as dedication to procurement, will be critical.

\section{References}

[1] Naylor, Rosamond L., Adam Liska, Marshall B. Burke, Walter P. Falcon, Joanne C. Gaskell, Scott D. Rozelle, and Kenneth G. Cassman 2007. The ripple effect: biofuels, food security, and the environment Agronomy and Horticulture-Faculty Publications (University of Nebraska-Lincoln) Paper 386. 
[2] Tilman, David, Robert Socolow, Jonathan A. Foley, Jason Hill, Eric Larson, Lee Lynd, Stephen Pacala, John Reilly, Tim Searchinger, Chris Somerville, Robert Williams, 2009. Beneficial biofuels - the food, energy, and environment trilemma Science 325:270-271.

[3] Tscharntke, Teja, Yann Clough, Thomas C. Wanger, Louise Jackson, Iris Motzke, Ivette Perfecto, John Vandermeer, Anthony Whitbread, 2012. Global food security, biodiversity conservation and the future of agricultural intensification. Biological Conservation 151:53-59.

[4] Pimentel, David, Alison Marklein, Megan A. Toth, Marissa N. Karpoff, Gillian S. Paul, Robert McCormack, Joanna Kyriazis, Tim Krueger, 2009. Food versus biofuels: environmental and economic costs Human Ecology 37:1-12.

[5] ICO (International Coffee Organization) 2014. See the website link: http://www.ico.org/mission07_e.asp?section=About_Us accessed on 16 September 2014.

[6] Gao, Yan, Margaret Skutsch, Omar Masera and Pablo Pacheco, 2011. A global analysis of deforestation due to biofuel development. Working Paper 68. CIFOR, Bogor, Indonesia.

[7] Rice, RA 2013 Culture, agriculture, and nature. In Robert W. Thurston, Jonathan Morris and Swawn Steiman (eds) Coffee: A comprehensive guide to the bean, the beverage and the industry. Rowman and Littlefield: New York, pp. 41-52.

[8] Giovannucci, D. and J. Potts with B. Killian, C. Wunderlich, G. Soto, S. Schuller, F. Pinard, K. Schroeder, I. Vagneron 2008. Seeking sustainability: COSA preliminary analysis of sustainability initiatives in the coffee sector. IISD/Commmittee on Sustainability Assessment: Winnipeg, Canada 36pp.

[9] Vannini, J. 1994. Nearctic avian migrants in coffee plantations and forest fragments of south-western Guatemala. Bird Conservation International 4(2/3):209-232.

[10] Greenberg, R., P. Bichier, A. Cruz-Angon, and R. Reitsma 1997a. Bird populations in shade and sun coffee plantations in central Guatemala. Conservation Biology 11(2):448-459.

[11] Greenberg, R., P. Bichier and J. Sterling 1997b. Bird populations in rustic and planted shade coffee plantations of eastern Chiapas, Mexico. Biotropica 29(4):501-514.

[12] Greenberg, R., P. Bichier, A. Cruz-Angon, C. MacVean, R. Perez and E. Cano 2000. The impact of avian insectivory on arthropods and leaf damage in some Guatemalan coffee plantations. Ecology 81(6):1750-1755.

[13] Document archived at the Smithsonian's Migratory Bird Center, National Zoological Park, Washington, DC.

[14] Rice, R. and J. Ward 1996. Coffee, conservation and commerce in the western hemisphere: how individuals and institutions can promote ecologically sound farming and forest management in northern Latin America. Smithsonian Migratory Bird Center/Natural Resources Defense Council: Washington, DC 47pp.

[15] Rice, R., A. Harris and J. McLean 1997. Proceedings of the $1^{\text {st }}$ sustainable coffee congress. Smithsonian Migratory Bird Center: Washington, DC 445pp.

[16] CPCP, 2001. Conservation principles for coffee production, Consumer's Choice Council, Washington, DC. May, 2001.

[17] Starbucks http://www.starbucks.com/responsibility/sourcing/coffee Accessed 25 September 2014.

[18] UTZ Certified, https://www.utzcertified.org/aboututzcertified/the-story-of-utz Accessed 25 September 2014.

[19] 4C Program, http://www.4c-coffeeassociation.org/aboutus/history.html\#2 Accessed 25 September 2014.

[20] Nespresso AAA Program, website accessed October, 2014: http://www.nestlenespresso.com/ecolaboration/sustainability/coffee

[21] Smithsonian Migratory Bird Center, www.si.edu/smbc , website accessed 20 September 2014.

[22] Goodland, R. 2002. Ecolabeling: opportunities for progress toward sustainability. Consumers Choice Council: Washington, DC 29pp.

[23] Ponte, Stefano, 2004. Standards and sustainability in the coffee sector: a global value chain approach. International Institute for Sustainable Development (www.iisd.org).

[24] STAP, 2010. Environmental certification and the GEF: a STAP advisory document. UN Environmental Program/Global Environment Facility; (www.unep.org/stap)

[25] Tscharntke, Teja, Jeffrey C. Milder, Götz Schroth, Yann Clough, Fabrice DeClerck, Anthony Waldron, Robert Rice, Jaboury Ghazoul, 2014. Conserving biodiversity through certification of tropical crops at local and landscape scales. Conservation Letters, doi: 10.1111/conl.12110.

[26] Blackman, Alen. and Jorge Rivera, 2011. Producer-level benefits of sustainability certification. Conservation. Biology 25:1176-1185.

[27] World Business Council for Sustainable Development 2007, Biofuels Issue Brief, Energy and Climate Focus Area, WBCSD: Geneva, Switzerland 12 pp. Downloaded at: http://www.wbcsd.org/Pages/EDocument/EDocumentDetails.a spx?ID $=106 \&$ NoSearchContextKey=true 